\title{
Improving the completeness of anaesthesia record charts for obstetric subarachnoid block among third year anaesthesia students in University of Gondar
}

\author{
Wubie Birlie Chekol ${ }^{*}$, Abraham Tarekegn Mersha ${ }^{1}$, Nurhussien Riskey Arefaynie ${ }^{1}$, Seid Adem \\ Ahmed $^{1}$ \\ Lecturer ${ }^{1}$, Department of Anesthesia, College of Medicine and Health Sciences, University of Gondar, \\ Gondar, Northwest Ethiopia.
}

\begin{abstract}
Introduction:
Documentation during obstetrics spinal anaesthesia will demand accuracy and completeness for maternal and neonatal safety. Third year anaesthesia students are the pioneer participants in documentation of perioperative information. This audit aimed to improve the documentation trends of third year anaesthesia students after subarachnoid obstetric anaesthesia.
\end{abstract}

\section{Methods:}

It was conducted from April to May 13, 2019 in University of Gondar Referral Hospital at maternity wards. Data were analyzed with SPSS version 20. Categorical variables were analyzed with chisquare test.

\section{Results:}

Documentation completion was $58.2 \%$ before interventions and $81.13 \%$ after interventions. Documentation completion of hospital number, name of the surgeon and urine output significantly improved after interventions

\section{Conclusions:}

This audit identified significant improvements of post intervention documentation of patient's data such as patient height, preoperative blood pressure and baseline saturation. So, we recommend having regular lecturing and re-auditing of documentation trends of our third year anaesthesia students.

Key points: documentation; obstetrics anaesthesia; spinal anaesthesia; record keeping

\section{Introduction}

Anaesthetic record charting in obstetrics subarachnoid block is a piece of information that is useful in monitoring maternal and neonatal safety. Spinal anaesthesia is widely practiced as the anaesthetic technique for obstetric patients. Record keeping during obstetric spinal anaesthesia

\footnotetext{
*Correspondence: Wubie Birlie Chekol

E mail: birliewubie@gmail.com
}

https://orcid.org/0000-0001-9438-8840

Received: 26/11/2019

Accepted: 09/03/2020

DOI: http:/doi.org/10.4038/slja.v28i2.8520

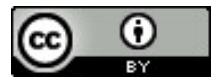

will demand accuracy and completeness for maternal and neonatal safety. The record sheet should be concise and complete of relevant information such as preoperative history, perioperative medications, vital signs, newborn parameters and immediate postoperative care instructions. Moreover, it is important for the purpose of legal requirement and to reduce maternal complications which are more common in obstetric anaesthesia than other specialties. ${ }^{1-3}$

Documenting and keeping readily accessible records are responsibilities of anaesthesia practitioners and anaesthetists. ${ }^{4-6}$ The anaesthetic record has become a key element of good anaesthetic practices, which is helpful for other staff who will be involved in the management of the patients. It will safeguard against medico legal 
issues, facilitate effective monitoring of patients and is an important tool for research and audit and quality improvement in anaesthesia. It allows for appropriate management of perioperative anaesthesia, is useful to improve patient's recall of risks and benefits and to get briefed information during hand over of operated patients and to request written rather than verbal communication. $4,7,8$

Poor habit of documentation will lead to legal implications, high mortality and morbidity rate, poor patient management and safety and poor coherence of patient's approach. All of these functions depend on the completeness of the record and on the relevance and comprehensiveness of the data recorded..$^{9-11}$

\section{Justification}

The level of anaesthetic record completeness is substandard in our hospital when compared with the recommendations of AABGI. Appropriate education of personnel involved in charting anaesthetic record has been found to improve its completeness and correctness. The components and the quality of anaesthetic record chart in obstetric regional anaesthesia have reported incompleteness as their major findings. ${ }^{2,3,12}$ Third year anaesthesia students are the pioneer participants in documentation of perioperative information of the patients. However, they got their documentation experiences with their informal learning from their seniors.

Lecturing on record keeping of perioperative anaesthesia events as well as rounding of students by clarifying a sample filled documentation form is so vital to improve the completeness of our record keeping. ${ }^{1}$ So we aimed to conduct this audit to improve the documentation trends of third year anaesthesia students and to assess the impact of regular gap lecturing and training on anaesthesia record keeping after subarachnoid obstetric anaesthesia.

\section{Methods \\ Study design and period}

Comparative study was conducted from April 1 to May 13, 2019 in University of Gondar Referral Hospital at maternity wards.

\section{Source population/ study population}

Anaesthetic record sheet after subarachnoid block of obstetric patients which was documented by third year anaesthesia students

\section{Inclusion criteria}

All anaesthetic record sheets for subarachnoid block of obstetric patients which were documented by third year anaesthesia students during the study period.

\section{Exclusion criteria}

Documentation that was converted to general anaesthesia, documentation done by other than third year anaesthesia students.

\section{Sample size and sampling technique}

Consecutive sampling technique was used for documentations which were done by all third year anaesthesia students during the study period.

\section{Data collection procedures}

Structured questionnaires were prepared from the anaesthetic record sheet of University of Gondar Referral Hospital after reviewing the contents against the minimum data set for an anaesthetic record by the Royal College of Anaesthetists and Association of Anaesthetists of Great Britain and Ireland (AAGBI). We reviewed a total of 100 anaesthetic record sheets after the transfer of the patient to the recovery room of obstetrics ward. Socio-demographic information that reviewed on the chart were patient's name, patient's age, hospital number, date of surgery, name of the anaesthetists, name of the surgeon, ASA classification, height, weight, date of surgery.

Perioperative information that were reviewed on the chart were preoperative pulse, baseline saturation, preoperative blood pressure, intraoperative pulse rate, intraoperative saturation, intraoperative blood pressure, time of spinal block, vertebral space, level of the nerve block, delivery time, time of skin incision, fluid intake, recovery condition, preoperative summary, urgency of surgery, urine output and APGAR score.

\section{Data processing and analysis}

Data were coded, entered and analyzed using Statistical Package for Social Science (SPSS) version 20 software. Categorical variables were analyzed with chi-square test and these descriptive 
statics were presented with frequency and percentage value $<0.05$ was considered as statistically significant.

\section{Results}

\section{Pre intervention results}

Table 1: Pre-intervention documentation completeness of socio-demographic and perioperative information

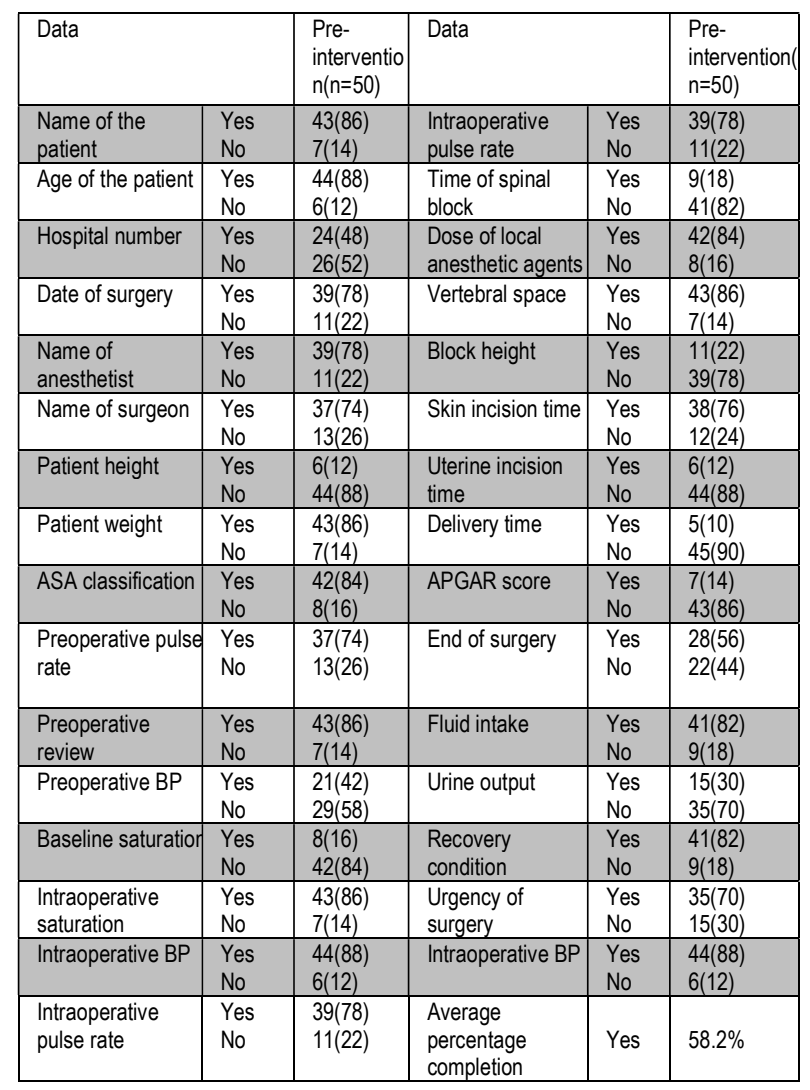

Data were expressed with frequency (percent) Identified problems for the proposed actions

This study mainly identified that patient data such as patient height, preoperative blood pressure, baseline saturation, time of spinal block, block height, uterine incision, delivery time, APGAR score, urine output and urgency of surgery were not recorded in pre intervention documentation. The average completion rate of our record sheet was low $(58.2 \%)$.

\section{Implemented actions}

Lecturing was done on emphasizing of the benefits of anaesthetic record keeping for subarachnoid block of obstetrics surgery and its components. Rounding of a sample of filled anaesthetic record sheets for five groups of students, 10 students per group was done by principal investigators. Immediately after lecturing and rounding of filled charts, reviewing of documentation completeness in their duty rotation were done on 50 anaesthetic record sheets after patient transfer to the recovery room of the maternity wards.

\section{Post intervention results}

A total of 100 anaesthetic record sheets, 50 documentation sheets before intervention and 50 post interventions were done of percentage completion. The assessments included both emergency and elective patients. The average percentages of documentation completion were $58.2 \%$ before intervention and $81.13 \%$ after interventions. Documentation completion of hospital number, name of the surgeon, patient height, baseline saturation and preoperative blood pressure, time of spinal block, block height, skin incision time, delivery time, APGAR score and urine output significantly improved after interventions. (Table 2) (Table 3)

Table 2: Documentation of socio-demographic information

\begin{tabular}{|c|c|c|c|c|}
\hline \multicolumn{2}{|c|}{ Variables for documentation } & \multirow{2}{*}{$\begin{array}{l}\text { Pre- } \\
\text { interventio } \\
n(n=50) \\
43(86) \\
7(14)\end{array}$} & \multirow{2}{*}{$\begin{array}{l}\text { Post } \\
\text { intervention(n } \\
=50) \\
\\
45(90) \\
5(10)\end{array}$} & \multirow{2}{*}{$\begin{array}{l}\text { P- value } \\
0.538\end{array}$} \\
\hline $\begin{array}{l}\text { Name of the } \\
\text { patient }\end{array}$ & $\begin{array}{l}\text { Yes } \\
\text { No }\end{array}$ & & & \\
\hline $\begin{array}{l}\text { Age of the } \\
\text { patient }\end{array}$ & $\begin{array}{l}\text { Yes } \\
\text { No }\end{array}$ & $\begin{array}{l}44(88) \\
6(12)\end{array}$ & $\begin{array}{l}45(90) \\
5(10)\end{array}$ & 0.749 \\
\hline Hospital number & $\begin{array}{l}\text { Yes } \\
\text { No }\end{array}$ & $\begin{array}{l}24(48) \\
26(52)\end{array}$ & $\begin{array}{l}45(90) \\
5(10)\end{array}$ & $<0.001^{*}$ \\
\hline Date of surgery & $\begin{array}{l}\text { Yes } \\
\text { No }\end{array}$ & $\begin{array}{l}39(78) \\
11(22)\end{array}$ & $\begin{array}{l}46(92) \\
4(8)\end{array}$ & 0.050 \\
\hline $\begin{array}{l}\text { Name of } \\
\text { anesthetist }\end{array}$ & $\begin{array}{l}\text { Yes } \\
\text { No }\end{array}$ & $\begin{array}{l}39(78) \\
11(22)\end{array}$ & $\begin{array}{l}43(86) \\
7(14)\end{array}$ & 0.298 \\
\hline $\begin{array}{l}\text { Name of } \\
\text { surgeon }\end{array}$ & $\begin{array}{l}\text { Yes } \\
\text { No }\end{array}$ & $\begin{array}{l}37(74) \\
13(26)\end{array}$ & $\begin{array}{l}45(90) \\
5(10)\end{array}$ & $0.037^{*}$ \\
\hline Patient height & $\begin{array}{l}\text { Yes } \\
\text { No }\end{array}$ & $\begin{array}{l}6(12) \\
44(88)\end{array}$ & $\begin{array}{l}40(80) \\
10(20)\end{array}$ & $<0.001^{*}$ \\
\hline Patient weight & $\begin{array}{l}\text { Yes } \\
\text { No }\end{array}$ & $\begin{array}{l}43(86) \\
7(14)\end{array}$ & $\begin{array}{l}44(88) \\
6(12)\end{array}$ & 0.766 \\
\hline $\begin{array}{l}\text { ASA } \\
\text { classification }\end{array}$ & $\begin{array}{l}\text { Yes } \\
\text { No }\end{array}$ & $\begin{array}{l}42(84) \\
8(16)\end{array}$ & $\begin{array}{l}45(90) \\
5(10)\end{array}$ & 0.372 \\
\hline
\end{tabular}


P-value $\leq 0.05$ is considered as statistically significant. Data is expressed with frequency (\%).

Table 3: Documentation of perioperative information

\begin{tabular}{|c|c|c|c|c|}
\hline \multicolumn{2}{|c|}{ Variables for documentation } & \multirow{2}{*}{$\begin{array}{l}\begin{array}{l}\text { Pre- } \\
\text { interven } \\
\text { tion } \\
(\mathbf{n}=\mathbf{5 0})\end{array} \\
37(74) \\
13(26)\end{array}$} & \multirow{2}{*}{$\begin{array}{l}\begin{array}{l}\text { Post } \\
\text { interventi } \\
\text { on }(\mathbf{n}=\mathbf{5 0})\end{array} \\
44(88) \\
6(12)\end{array}$} & \multirow{2}{*}{$\begin{array}{l}\text { P- value } \\
0.074\end{array}$} \\
\hline $\begin{array}{l}\text { Preoperative pulse } \\
\text { rate }\end{array}$ & $\begin{array}{l}\text { Yes } \\
\text { No }\end{array}$ & & & \\
\hline Preoperative review & $\begin{array}{l}\text { Yes } \\
\text { No }\end{array}$ & $\begin{array}{l}43(86) \\
7(14)\end{array}$ & $\begin{array}{l}45(90) \\
5(10)\end{array}$ & 0.538 \\
\hline Preoperative BP & $\begin{array}{l}\text { Yes } \\
\text { No }\end{array}$ & $\begin{array}{l}21(42) \\
29(58) \\
\end{array}$ & $\begin{array}{l}40(80) \\
10(20) \\
\end{array}$ & $<0.001 *$ \\
\hline Baseline saturation & $\begin{array}{l}\text { Yes } \\
\text { No }\end{array}$ & $\begin{array}{l}8(16) \\
42(84) \\
\end{array}$ & $\begin{array}{l}41(82) \\
9(18) \\
\end{array}$ & $<0.001^{*}$ \\
\hline $\begin{array}{l}\text { Intraoperative } \\
\text { saturation }\end{array}$ & $\begin{array}{l}\text { Yes } \\
\text { No }\end{array}$ & $\begin{array}{l}43(86) \\
7(14) \\
\end{array}$ & $\begin{array}{l}44(88) \\
6(12) \\
\end{array}$ & 0.766 \\
\hline Intraoperative BP & $\begin{array}{l}\text { Yes } \\
\text { No }\end{array}$ & $\begin{array}{l}44(88) \\
6(12)\end{array}$ & $\begin{array}{l}45(90) \\
5(10)\end{array}$ & 0.749 \\
\hline $\begin{array}{l}\text { Intraoperative pulse } \\
\text { rate }\end{array}$ & $\begin{array}{l}\text { Yes } \\
\text { No }\end{array}$ & $\begin{array}{l}39(78) \\
11(22) \\
\end{array}$ & $\begin{array}{l}45(90) \\
5(10)\end{array}$ & 0.102 \\
\hline Time of spinal block & $\begin{array}{l}\text { Yes } \\
\text { No }\end{array}$ & $\begin{array}{l}9(18) \\
41(82) \\
\end{array}$ & $\begin{array}{l}39(78) \\
11(22) \\
\end{array}$ & $<0.001^{*}$ \\
\hline $\begin{array}{l}\text { Dose of local } \\
\text { anesthetic agents }\end{array}$ & $\begin{array}{l}\text { Yes } \\
\text { No }\end{array}$ & $\begin{array}{l}42(84) \\
8(16)\end{array}$ & $\begin{array}{l}45(90) \\
5(10)\end{array}$ & 0.372 \\
\hline Vertebral space & $\begin{array}{l}\text { Yes } \\
\text { No }\end{array}$ & $\begin{array}{l}43(86) \\
7(14) \\
\end{array}$ & $\begin{array}{l}45(90) \\
5(10) \\
\end{array}$ & 0.538 \\
\hline Block height & $\begin{array}{l}\text { Yes } \\
\text { No }\end{array}$ & $\begin{array}{l}11(22) \\
39(78)\end{array}$ & $\begin{array}{l}43(86) \\
7(14)\end{array}$ & $<0.001 *$ \\
\hline Skin incision time & $\begin{array}{l}\text { Yes } \\
\text { No }\end{array}$ & $\begin{array}{l}38(76) \\
12(24)\end{array}$ & $\begin{array}{l}47(94) \\
3(6)\end{array}$ & $0.012^{*}$ \\
\hline Uterine incision time & $\begin{array}{l}\text { Yes } \\
\text { No }\end{array}$ & $\begin{array}{l}6(12) \\
44(88) \\
\end{array}$ & $\begin{array}{l}35(70) \\
15(30) \\
\end{array}$ & $<0.001 *$ \\
\hline Delivery time & $\begin{array}{l}\text { Yes } \\
\text { No }\end{array}$ & $\begin{array}{l}5(10) \\
45(90)\end{array}$ & $\begin{array}{l}25(50) \\
25(50)\end{array}$ & $<0.001^{*}$ \\
\hline APGAR score & $\begin{array}{l}\text { Yes } \\
\text { No }\end{array}$ & $\begin{array}{l}7(14) \\
43(86) \\
\end{array}$ & $\begin{array}{l}20(40) \\
30(60) \\
\end{array}$ & $0.003^{*}$ \\
\hline End of surgery & $\begin{array}{l}\text { Yes } \\
\text { No }\end{array}$ & $\begin{array}{l}28(56) \\
22(44) \\
\end{array}$ & $\begin{array}{l}46(92) \\
4(8) \\
\end{array}$ & $<0.001^{*}$ \\
\hline Fluid intake & $\begin{array}{l}\text { Yes } \\
\text { No }\end{array}$ & $\begin{array}{l}41(82) \\
9(18)\end{array}$ & $\begin{array}{l}43(86) \\
7(14) \\
\end{array}$ & 0.585 \\
\hline Urine output & $\begin{array}{l}\text { Yes } \\
\text { No }\end{array}$ & $\begin{array}{l}15(30) \\
35(70) \\
\end{array}$ & $\begin{array}{l}39(78) \\
11(22) \\
\end{array}$ & $<0.001 *$ \\
\hline Recovery condition & $\begin{array}{l}\text { Yes } \\
\text { No }\end{array}$ & $\begin{array}{l}41(82) \\
9(18) \\
\end{array}$ & $\begin{array}{l}4(88) \\
6(12) \\
\end{array}$ & 0.401 \\
\hline Urgency of surgery & $\begin{array}{l}\text { Yes } \\
\text { No } \\
\end{array}$ & $\begin{array}{l}35(70) \\
15(30) \\
\end{array}$ & $\begin{array}{l}44(88) \\
6(12) \\
\end{array}$ & $0.027^{*}$ \\
\hline $\begin{array}{l}\text { Average percentage } \\
\text { completion }\end{array}$ & & $58.2 \%$ & $81.13 \%$ & \\
\hline
\end{tabular}

P-value $\leq 0.05$ is considered as statistically significant. Data is expressed with frequency (percent)

\section{Discussion}

This audit assessed the improvements in documentation completion of third year anaesthesia students in the perioperative period of subarachnoid block for obstetric patients. The average percentages of completion were $58.2 \%$ before intervention and $81.13 \%$ after interventions. There was significant improvement of post intervention documentation of hospital number, name of the surgeon, patient height, baseline saturation, preoperative blood pressure, time of spinal block, block height, skin incision time, delivery time, APGAR score and urine output.

In this study the socio-demographic data such as patient name, patient age, date of surgery, name of the anaesthetists, ASA classification, weight and date of surgery documentation were not significantly different before and after interventions. The adequacy of these documentations was good both before and after lecturing. However, there were significant improvements in documentation of patient height, surgeon name and hospital number after interventions.

Similarly, Simon et al supported these data, even though patient's weight and height were poorly documented at pre-intervention phase of their study. ${ }^{1}$

Desalu et al and Simon et al reported that there were significant improvements in documentation postintervention in ASA classification, preoperative blood pressure, dose of bupivacaine, vertebral space used, end of surgery time and time of skin incision. ${ }^{1,9,13}$ Our results on skin incision time and end of surgery were consistent with their results.

According to this study, preoperative review, intraoperative saturation, intraoperative blood pressure, intraoperative pulse rate, recovery condition, fluid intake, vertebral space and dose of bupivacaine were documented in a good manner both at pre-intervention and post intervention phases.

As Simon et al reported the documentation completion of baseline saturation, uterine incision time and urine output after interventions were 33\%, $61 \%$ and $70 \%$ respectively. ${ }^{1}$ In this study it was $82 \%, 70 \%$ and $78 \%$ respectively. This is a good indicator of the importance of regular teaching for students who will be involved in record keeping of perioperative events.

Incomplete documentation about perioperative information may be taken as negligence in case 
there are any perioperative complications. Earlier literature reported that there were overall improvements in the filling of anaesthetic record sheets after teaching interventions ${ }^{1,9,14,15}$ This study also supported their conclusions.

Spinal anaesthesia is the commonly applied anaesthetic techniques for obstetrics anaesthesia. Subarachnoid blocks are mainly done for cesarean sections, but secondary complications will happen related with documentation problems. So, we should emphasize for complete documentation. However if there is lack of adequate perioperative documentation, it will hinder the quality and safety of patient management, lead to legal implications and difficulty in getting briefed information during handover period. ${ }^{4,5,15,16}$ Also adequate documentation of perioperative anaesthetic events will be valuable to subsequent anaesthetists who required to provide anaesthetic services to a patient for the future. ${ }^{15,17,18}$

\section{Conclusions}

This audit identified that there were significant improvements of post intervention documentation. We recommend having a regular lecturing method and re auditing of documentation trends of our third year anaesthesia students.

\section{Declaration}

Funding: No funding was received

Conflicts of interest: The authors declared that they have no conflicts of interest.

Acknowledgements: University of Gondar, HDP leaders, data collectors, supervisors and study participants for their invaluable support.

\section{References}

1. Simeon, O.O., T.A. Anthony, and M.O. Afolabi, The effect of teaching on the completeness of the anesthesia record charts for obstetric subarachnoid blocks in a low resource area hospital. Journal of Obstetric Anaesthesia and Critical Care 2015. 5(1): 16-21 https://doi.org/10.4103/2249-4472.155194

2. Chimhundu, S.T., S. Shumbairerwa, and F.p. Madzimbamuto, Development of an Obstetric Anesthesia Chart using the Digital Pen and Paper in a Low Resource Setting:A Prospective Interventional Study. Global Journal of Medical Research, 2018. 18 (8):5-12

3. Kopic D, Sedensky M, Owen M. The impact of a teaching program on obstetric anesthesia practices in Croatia. Int J Obstet Anesth 2009;18:4-9. https://doi.org/10.1016/j.ijoa.2008.04.007 PMid:18691873

4. Chekol WB, Denu ZA, Tawuye HY, et al. Audit on documentation completeness after regional nerve blocks at University of Gondar referral hospital,J of Anes\& Cri Open Access. 2018;10(6):208-211. https://doi.org/10.15406/jaccoa.2018.10.00390

5. Gebremedhn EG, Nagaratnam .Audit on Anaesthetic Record Completeness at A University Teaching Hospital Operation Theater of Low Resource Setting,J Anesth Crit Care Open Access,2017: $\quad$ 8(2):00298. https://doi.org/10.15406/jaccoa.2017.08.00298

6. Zollinger RM Jr, Kreul JF, Schneider AJ. Manmade versus computer-generated anesthesia records. J Surg Res 1977; 22:419-24. https://doi.org/10.1016/0022-4804(77)90165-2

7. Woldegerima YB, Kemal SD. Clinical audit on the practice of documentation at preanesthetic evaluation in a specialized university hospital. Anesth Essays Res 2018;12:819-24.

8. van Schalkwyk JM, Lowes D, Frampton C, Merry AF. Does manual anaesthetic record capture remove clinically important data? $\mathrm{Br} \mathrm{J}$ Anaesth 2011;107:546-52.

https://doi.org/10.1093/bja/aer163

PMid:21665898

9. Desalu I, Olanipekun O, Agbamu P. An audit of anaesthesia record keeping at the Lagos University Teaching Hospital. Afr J Anaesth Int C 2010;10:15. https://doi.org/10.4314/ajaic.v10i1.60591

10. Varma S. Anaesthetic record keeping during caesarean section. Online J Clin Audits 2009;1:2437.

11. Hongkong College of Anesthesiologists. Guidelines on Monitoring in Anesthesia. Hongkong: HKCAPI-v3; 2012.

12. Jin HS, Kim MH, Lee SY, Jeong HY, Choi SJ, Lee HW. A survey of user acceptance of electronic patient anesthesia records. Korean J Anesthesiol 2012;62:350-7. https://doi.org/10.4097/kjae.2012.62.4.350 PMid:22558502 PMCid:PMC3337382 
13. Elhalawani, I., S. Jenkins, and N. Newman, Perioperative anesthetic documentation: Adherence to current Australian guidelines. Journal of anaesthesiology, clinical pharmacology, 2013. 29(2): $\mathrm{p}$.

https://doi.org/10.4103/0970-9185.111726

PMid:23878444 PMCid:PMC3713670

14. Chiu M, Arab AA, Elliott R, Naik VN. An experiential teaching sessionon the anesthesia machine check improves resident performance. Can J Anaesth 2012;59:280-7. https://doi.org/10.1007/s12630-011-9649-5

PMid:22194153

15. Gerancher J, Viscusi E, Liguori G. Development of a Standardized Peripheral Nerve Block Procedure Note Form. Reg Anesth Pain Med,2005;30(1):6771. https://doi.org/10.1097/00115550-200501000$\underline{00008}$

PMid:15690271

16. Samarkandi A. Status of medical liability claims in Saudi Arabia. Ann Saudi Med 2006;26:87-91. https://doi.org/10.5144/0256-4947.2006.87 PMid:16761443 PMCid:PMC6074163

17. Raff M, James MF. An audit of anaesthetic record keeping. South Afr J Anesth Analg 2003;9:7-9. https://doi.org/10.1080/22201173.2003.10873005

18. Moran PJ, Fennessy P, Johnson MZ. Establishing a new national standard for the documentation of regional anaesthesia in Ireland.BMJ Open Quality 2017; 6:e000210. doi:10.1136/ bmjoq-2017-000210 